\title{
İkinci Dünya Savaşı ve Sonrasında Sovyet Yahudileri (Rusça Kaynaklar Işı̆̆ında)
}

\section{Soviet Jews during and after the World War II (In the Light of Russian Sources)}

\author{
Şir Muhammed Dualı*
}

Öz

Bugün İsrail nüfusunun önemli bir bölümü, eski Sovyetler Birliğinden göç eden Yahudilerden oluşmaktadır. Bunun nedeni ise Sovyetlerin üç milyon civarında Yahudiye ev sahipliği yapmış olmasıdır. Hem Çarlık dönemi hem de Sovyetler zamanında milyonlarca Yahudi Rusya'nın kontrolü altındaki topraklarda yaşamışlardır. Bu durum bazen Yahudiler ile Ortodoks Ruslar arasında bir gerilime bazen de çatışmalara neden olmuştur. Çarlık döneminde genellikle dini ve ekonomik nedenlerle Yahudiler hedef alınırken, Sovyetler döneminde ise daha ziyade siyasi gerekçelerle hedef tahtasına oturtulmuşlardır. Bu makale, Sovyet Yahudilerinin ikinci Dünya Savaşı ve sonrasında yaşadıkları zorlukları ve buna neden olan sebepleri konu edinmektedir. Bu çerçevede özellikle Stalin'in Yahudi politikası ve yaşanan baskılar ele alınmaktadır. Ayrıca Stalin sonrası Sovyet Yahudilerinin durumu, eğitim ve inanç alanındaki konumları ele alınmaktadır. Son olarak da ateist bir rejim içerisinde dahi olsa Yahudilerin hedef alınmasının nedenleri üzerinde durulmaktadır.

\section{Anahtar Kelimeler}

Sovyetler Birliği, Yahudiler, İkinci Dünya Savaşı, Stalin, Baskı ve Takip

\begin{abstract}
An significant portion of the Israeli population today consists of Jews emigrating from the former Soviet Union. This is because the Soviets hosted around three million Jews. Millions of Jews lived in the territory under the control of Russia, both during the Tsarist period and during the Soviet period. This situation sometimes caused tension and conflicts between Jews and Orthodox Russians. In the Tsarist period, Jews were generally targeted for religious and economic reasons, while in the Soviet period they were mostly targeted for political reasons. This article focuses on the difficulties that Soviet Jews experienced in World War two and beyond and the reasons behind these difficulties. In this framework, Stalin's Jewish policy and pressures in particular are discussed. In addition, the situation of post-Stalin Soviet Jews in education and faith is discussed. Finally, the reasons for targeting Jews by an atheist regime are emphasized.
\end{abstract}

\section{Keywords}

Soviet Union, Jews, World War II, Stalin, Repression and Tracking

\footnotetext{
* Sorumlu Yazar: Şir Muhammed Dualı (Doç. Dr.), Gaziosmanpaşa Üniversitesi, illahiyat Fakültesi / Felsefe ve Din Bilimleri Bölümü, İstanbul, Türkiye. E-posta: muhammed.duali@gop.edu.tr ORCID: 0000-0003-0136-1214

Atrf: Sir Muhammed Duali, “ikinci Dünya Savaşı ve Sonrasında Sovyet Yahudileri (Rusça Kaynaklar Işığında)." darulfunun ilahiyat 31, 2 (2020): 379-395. https://doi.org/10.26650/di.2020.31.2.0005
} 


\section{Extended Summary}

During the Second World War, the Germans were cruel to the Jews. They declared their war against Russia as a war against the Bolshevik Jews who surrounded Moscow. With this claim, the Germans aimed to gain the sympathy of the Orthodox Russian society and break the resistance. However, the Russian Orthodox Church declared that it was with the state against the German attack and tried to frustrate this move by the Nazis. The rapid advance of the Germans resulted in hundreds of thousands of Jews seeking refuge with the Soviets, even on the border, and escaping the German occupation. A significant number of these Jews had migrated far from the front line to the inner parts of Russia. During the war, around five hundred thousand Jews fought against the Germans on the Soviet fronts. In this process, Stalin made some decisions to provide liberties for Soviet people. The primary one was loosening the existing bans on religious communities' beliefs. This positive approach to religions also affected the Jewish community, and dozens of synagogues began to serve their religious purposes again. In the years after the war, especially with the establishment of Israel in 1948, multiple changes occurred in the Jewish policy of the Soviets. The Soviets, who supported Israel in the first stage, withdrew this support as Israel approached the Western bloc and turned towards supporting the Arab states against Israel. ${ }^{1}$ Thousands of Jews wanted to immigrate to Israel after the establishment of Israel. The Jews' demands to immigrate to Israel, prompted the Stalin regime to take drastic precautions. In this framework, monitoring of Jews was initiated. At the same time, serious restrictions were imposed on religious, cultural and educational fields. ${ }^{2}$ In addition, Soviet Jews were prevented from going abroad. In an environment of cold winds in the Soviet-Israeli relationship, and after Stalin's illness, this placed the Jewish doctors working in the Kremlin under suspicion. It was alleged that Kremlin doctors, allegedly affiliated with an international Jewish nationalist organization (American Jewish Joint Distribution Committee), had attempted to poison Stalin and senior Soviet administrators. Over time, this claim was accepted by Stalin and a comprehensive investigation was launched against Kremlin doctors. In this context, dozens of doctors were arrested, including Professor Aleksey Andreyevich Busalov. $^{3}$

These policies and strict measures taken by the Soviet administration against the Jews also found a response in the Russian society. Of all these tensions, the bomb attack on the Soviet consulate in Tel Aviv in 1953 resulted in the breaking of diplomatic relations between the two countries. After Stalin's death, Khrushchev became the leader of the

1 Виктор Иванович Козлов, Евреи в России - СССР: реалии жизни и мифы, Москва: Русская Правда, 2010, s. 177.

2 Яков Рабинович, Бит Евреям в России; Спасибо Соложеницину, Москва, 2005, s. 275.

3 Геннадий Васильевич Костырченко, Тайная политика Сталина. Власть и антисемитизм, Издатель, Международные отношения, Москва, 2003, s. 643. 
party. He made partial changes in oppressive policies and ended the pursuit of Russian Jews. A new claim was made in 1952. According to this claim, Stalin was planning to drive all the Jews in big cities, especially Moscow, to Siberia. Aiming to turn the situation in its favor in this process, Israel tried to pave the way for the immigration of Soviet Jews to Israel by increasing international pressure on Stalin. ${ }^{4}$ As a result, the rumor that Soviet Jews were being deported to Siberia only came to an end with Stalin's death on March $5,1953$.

According to 1960 statistics, the total population of the Soviet Union was around 208 million. Of these, 2.5 million were Jews. ${ }^{5}$ New hopes arose for Soviet Jews after Stalin's death. The first of these was the removal of obstacles to the publication of newspapers and magazines in Hebrew (Idish) again. As a matter of fact, by 1961, Jews had the right to publish a magazine under the name of Sovetish Heymland (Soviet Homeland). ${ }^{6}$ The ban on Jewish travel abroad was also partially lifted, and a certain number of immigrations to Israel were approved. Jews again began to be influential in education and the arts. The existing restrictions on the fulfillment of religious duties in the resurgent synagogues were also eliminated. Only the ban regarding circumcision continued, which was carried out in the homes accompanied by rabbi. In summary, Jews have been subjected to pressure and monitoring and, in some cases, to slaughter, because of their beliefs among the communities they have lived throughout history. ${ }^{7}$ However, it is possible to say that political reasons are at the forefront rather than religious sensibilities in the Soviet Union, on the basis of the Jews oppression or monitoring. While the Jews' influence at various levels of the State disturbed the Russian society and thus the politicians, Israel's Westernoriented policies and Russian Jewish immigration demands to Israel prompted the Soviet administration to take some measures. Therefore, Jews who were oppressed for religious reasons during the Tsarist Russia were subjected to monitoring in Soviet Russia due to their attachment to Israel.

4 Костырченко, Тайная политика Сталина, s. 673.

5 Андрей Дикий, Евреи в России и в СССР, Новосибирск, 2005, s. 229.

6 Козлов, Евреи в России - СССР, s. 208.

7 Александр Солженицын: Двести лет вместе, Часть 2, (1917-1995) Русский путь, s. 2002 


\section{İkinci Dünya Savaşı ve Sonrasında Sovyet Yahudileri}

\section{(Rusça Kaynaklar Işı̆̆ında)}

Sovyetlerin tesisinde çok önemli bir rol oynayan Yahudilerin, Lenin'in ölümünden sonra bürokrasideki etkinlikleri her geçen gün daha da zayıflamaya yüz tutmuştur. Bunun temel nedeni Sovyetlerin başına geçen Stalin'in uyguladığı politikalardır. Stalin' in Yahudi Lev Troçki (ö. 1940) ile giriştĭgi iktidar mücadelesinin de bu süreçte etkili olduğu söylenebilir. Stalin' in dikte rejimi, daha önce Sovyet bürokrasisinde çok etkin olan Yahudilerin birer birer saf dışı bırakılmasına imkân tanıdı. Böylelikle 1925 yılına değin Sovyet bürokrasisinde önemli bir etkinliği olan Yahudiler, 1939 yılına gelindiğinde önemli ölçüde etkisini yitirdi. Lakin İkinci Dünya Savaşı'nın başladığ 1 yıl içerisinde Sovyetlerin Batı Ukrayna, Belarus, Moldova ve Baltık ülkelerini ilhak etmesi, bu bölgelerde yaşayan yüzbinlerce Yahudi'nin Sovyet yönetimi altına girmesi ile neticelendi ki bunun sonucunda üç milyon civarında olan Sovyet Yahudi'sinin sayısı beş milyona yükselmiş oldu. Bu durum Sovyet yönetimini Yahudilere yönelik yeni bir politika geliştirmeye mecbur bıraktı. Hem İkinci Dünya Savaşı boyunca hem de savaştan sonraki yıllarda Sovyet yönetimi Yahudilere yönelik birtakım tedbirler hayata geçirdi. Savaş yıllarında Nazi zulmünden kaçarak Sovyetlere sığınan ve öteden beri sınır hatlarında ikamet eden Yahudiler ülkenin iç kısımlarına göç ettirildiler. Ayrıca yüzbinlerce Yahudi orduda silahaltına alınarak cepheye sürüldü. Savaş sonrasında ise Sovyet Yahudileri açısından çok daha zorlu bir dönem başlamış oldu. Özellikle 1948 yılında İsrail'in kurulması ve kurulan bu devletin de Batı bloğundan yana tavır alması hem devletin siyasetinde hem de Rus toplumunda yeni bir tür Yahudi karşıtlığını körüklemiş oldu. Artık sağlıkta, akademide ve sanat alanında Yahudiler takibe maruz kalmakta, ülkeden ayrılmalarına da izin verilmemekteydi. Özellikle Stalin'in rahatsızlığının ağırlaştığı 1952-1953 yılları içerisinde Yahudi akademisyenler ve doktorlar ağır suçlamalarla karşı karşıya bırakıldılar. Durum öyle bir hal aldı ki artık yeni bir Yahudi kıyım ve sürgününün her han başlayabileceği endişesi tüm Sovyet Yahudilerini endişe ve korkuya sevk etti. 1953 yılında Stalin'in ölümü ile birlikte yeni bir döneme girilecek ve tüm bu korku ve edişe yerini umuda bırakacaktır.

\section{İkinci Dünya Savaşı Sırasında Sovyet Yahudileri}

1940 yılı itibarıyla Sovyetlerin dünyanın en kalabalık Yahudi nüfusuna ev sahipliği ediyor olması, Nazi Almanya'sının dikkatinden kaçmamıştır. Sovyetlere karşı savaş başlatan Naziler, Rus toplumunda var olan Yahudi karşıtllı̆ını ön plana çıkartarak bir algı yaratmaya çalıştılar. Şöyle ki dönemin Nazi propaganda bakanı Paul Joseph Goebbels, (ö. 1945) Almanların Ruslarla bir sorununun olmadığını, asıl hedeflerinin Avrupa'yı tehdit eden Yahudi-Bolşevik rejimi olduğunu dile 
getirmekteydi. ${ }^{8}$ Almanlar bu politikalarıyla açıkça Yahudileri hedef alırken, Yahudi karşıtlığ 1 ile bilinen Ortodoks Rus toplumuna da bir mesaj vermiş oluyorlardı. Bu çerçevede İkinci Dünya Savaşı boyunca Almanların Yahudilere karşı uyguladıkları şiddet politikası, on binlerce Yahudi'nin Sovyet kontrolü altındaki topraklara sığınması ile neticelenirken, sınır bölgelerde yaşayan Yahudi nüfusun da iç kesimlere doğru göç ettirilmesine yol açtı. Bu süreçte cephe hattında bulunan diğer toplumların da göçe tabi tutulmuştur. Cephe hattından göç ettirilen toplam Sovyet insanının sadece \%20'si Yahudilerden oluşmaktadır. 200 milyonluk bir Sovyet toplumunda bulunan beş milyon Yahudiye oranla göç ettirilenlerin \%20'nin Yahudi olması büyük bir yüzdelik dilimi oluşturmaktadır. Bu, söz konusu bölgelerde Yahudi popülasyonunun yoğun olmasından kaynaklanmaktadır. Cephe hattından kurtarılan Yahudiler, Orta Asya ve Rusya'nın iç kesimlerine yerleştirildiler. Diğer taraftan Almanların beklenmedik ilerleyişi ve kısa bir zaman diliminde Sovyetlerin batı vilayetlerini işkâl etmesi, bölgede bulunan önemli sayıdaki Yahudi'nin de Almanların eline geçmesine yol açtı. Rus araştırmacı Kozlov'a göre bu süreçte 1,9 milyon Yahudi Almanların eline geçmiş, bunlardan 1,5 milyondan fazlası öldürülmüştür. ${ }^{9}$

Resmi verilere göre Sovyet yönetimi İkinci Dünya Savaşı boyunca 500 bin civarında Yahudi'yi silahaltına almıştır. Çarlık Rusya'sından farklı olarak Sovyet yönetimi, Yahudilerin üst düzey rütbelere yükseltilmesinde de bir beis görmemiştir. Araştırmacı Soljenitsin'e göre Kızıl Ordu saflarında 100'ün üzerinde General ve Amiral rütbesine yükseltilmiş Yahudi hizmet ediyordu. ${ }^{10}$ Ancak araştırmacı Rabinovich, 1940 yılı içerisinde Sovyet Ordu saflarında 196 civarında yüksek rütbeli Yahudi'nin hizmet ettiğini belirtmektedir. ${ }^{11}$ Bunun dışında genellikle Yahudiler teknisyen ve doktor gibi görevlerde, daha çok arka cephelerde görevlendirilmişlerdir.

Yukarıda değinildiği üzere İkinci Dünya Savaşı boyunca Nazi Almanya's1 tarafından milyonlarca Yahudi'nin katledildiği bilinmektedir. Biz burada Holokost tartışmasına girmeksizin savaş öncesi Sovyetler Birliğinde mevcut 3 milyon civarındaki Yahudi'nin savaş sonrasında yapılan nüfus sayımında ortaya çıkan oranı ile kıyaslayarak bir sonuca varmaya çalışacağız. İlk olarak şunu belirtelim ki SSCB'de İkinci Dünya Savaşı sonrası ilk nüfus sayımı 1959 yılında gerçekleştirildi. Bunun nedeni, Stalin'in savaş yıllarında verilen büyük kayıpların gün yüzüne çıkmasını istememiş olmasıdır. Böylelikle geçen zaman içerisinde oluşan boşluğun

8 Gennadiy V. Kostyrchenko, Taynaya Politika Stalina: Vlast i Antisemitizm, (Moskova., 2003), 59.

9 Viktor Kozlov, Yevrei v Rossii-SSSR, Realii Zhizni i Mify, (Moskva., Russkaya Pravda, 2010), 190.

10 Aleksandr Isayevich Solzhenitsyn, Dvesti Let Vmeste, (1917-1995) Chast Vtoraya, (Russkiy Put., 2002), 356.

11 Yakov Rabinovich, Bit Evreyem v Rossii: Spasibo Solojenitsinu, (Moskova., Algoritma, 2005), 269. 
kapatılması amaçlanmaktaydı. Stalin'in ölümünden sonra gerçekleştirilen genel nüfus sayımına göre, Sovyet sınırları içerisinde toplam 2,2 milyon civarında Yahudi yaşamaktaydı. 1939 verileri ile karşılaştırıldığında 2,8 milyon civarında bir azalmanın yaşandığı görülmektedir. Kozlov, 2,8 milyonun içerisinde asimile olan Yahudiler ile savaş sonrası Polonya'ya göç eden yüz binlerce Yahudi'nin de dâhil edildiğini yazmaktadır. ${ }^{12}$ Her ne olur ise olsun bu durum İkinci Dünya Savaşı boyunca SSCB sınırları içerisinde bulunan 2 milyonu aşkın Yahudi'nin yok olduğunu ortaya koymaktadır.

\section{Stalin ve Yahudiler}

1922 tarihli Rusya Sosyalist Federasyonu Sovyet Cumhuriyeti Ceza Kanunu'nun 58. maddesinde Sovyetler Birliği’nde dini ve ırki ayrımcılı̆̆ın yasaklandığı ve bu tür eylemlerin suç kabul edildiği belirtilmiştir. ${ }^{13}$ Bu maddenin varlığı, Sovyet toplumunun Yahudilere yönelik olumsuz bakış açısını değiştirmeye yetmemiştir. Bunun birinci nedeni Yahudilerin Rus toplumunun hafizasında bıraktığı olumsuz imaj iken bir diğeri de ilk dönem Sovyet bürokrasisinde mevcut Yahudi etkinliğidir. Bu duruma İkinci Dünya Savaşı sonrası Sovyet yönetiminin uyguladığı İsrail karşıtı politikaların da önemli katkısının olduğu söylenebilir. Özellikle İkinci Dünya Savaşından sonra Sovyetlerde yükselişe geçen Yahudi karşıtlığının temelinde İsrail devletinin uyguladığı politikalar yatmaktadır. Bu gerçekten hareketle Rus araştırmacı Kozlov, Sovyetlerin bir anti-semitizm değil anti Siyonizm politikasına sahip olduğunun altını çizmektedir. ${ }^{14}$ Sovyetlerin 1948 yılından itibaren Siyonizm'i hedef alan politikalar izlemesinin birden fazla nedeni vardır. İlki, savaş sonrası Sovyetlerin de desteği ile kurulan İsrail devletinin çok kısa zaman içerisinde Batılı devletlerden yana tavır almasıdır. Bir diğeri ise Sovyet Yahudilerinin İsrail devletinin uyguladığı Siyonist politikaların etkisi altında kalmalarıdır. Siyonizm rüzgârı sadece sıradan Sovyet vatandaşı Yahudileri değil, aynı zamanda Bolşevik ideolojisiyle yetişmiş önemli devrimci Yahudileri de etkisi altına almıştır. Bu hususta Mareşal Voroşilov'un (ö. 1969) Yahudi eşi Golda Gorbman'ın (Voroşilova) İsrail hakkındaki düşünceleri örnek verilebilir. Daha genç yaşlarda iken Sinagogu terk ederek Bolşevik saflarına katılan Gorbman, 1948 yılında İsrail devleti ilan edildiğinde etrafındakilere dönüp; "artık bizim de bir vatanımız var" dediği belirtilmektedir. ${ }^{15}$

12 Kozlov, Evreyi v Rossii, 193.

13 Ugolovnyy Kodeks Rossiyskoy Sotsialisticheskoy Federativnoy Sovetskoy Respubliki, 1922, Statya 58-10.

14 Kozlov, Evreyi v Rossii, 160.

15 Gennadiy Vasilyevic Kostyrchenko, Taynaya Politika Stalina. Vlast i Antisemitizm (Moskva., Mezhdunarodnye Otnosheniya, 2003), 404. 
$\mathrm{Bu}$ ve benzeri tutumlar, Sovyet ideolojisinin Yahudi kimliği karşısında anlamsız bir hale geldiğini göstermektedir.

Sovyet Yahudilerinin İsrail'e olan merakı özellikle Ekim 1948 tarihinde Moskova'ya gelen İsrail'in ilk Moskova büyükelçisi Golda Meerson'un binlerce Yahudi tarafından karşılanması ve akabinde İsrail'e iltica için resmi makamlara dilekçelerin verilmesi ile daha da belirgin hal almıştır. Dahası Stalin'e yazılan mektuplarda, İkinci Dünya savaşına katılmış Yahudilerden oluşan özel bir birliğin Filistin'e gönderilmesi istenmekteydi. Tüm bu gelişmeler karşısında Yahudilerin güvenilmez olduğunu düşünen Sovyet hükümeti, bazı tedbirlere başvurdu. İlk olarak dilekçe veren Yahudiler Moskova dışına sürülürken, Yahudi tiyatro ve gazeteleri birer birer kapatıldı. Ayrıca başta akademi ve sanat camiası olmak üzere devletin çeşitli kademelerinde etkin konumda olan Yahudilere yönelik de bir operasyon başlatıldı. Önde gelen Yahudiler, savaş sonrası yıllarda yaygınlık kazanan ve "dünya yurttaşlığı" ilkesini savunan kozmopolitanlıkla suçlandılar. Bu çerçevede özellikle akademide mevcut onlarca akademisyen görevden uzaklaştırıldı. ${ }^{16}$ Ayrıca Yahudi milliyetçiliği ile mücadele etmek adına özel bir teşkilatın oluşturtulması, alınan kararlar içerisinde yer almaktadır. 6. Bölüm olarak da bilinen bu teşkilatın görevi, Siyonist faaliyetlerde bulunan milliyetçi Yahudilerin takibi ve kontrol altına alınmasıydı. Bu bağlamda 1948 yılı içerisinde 956 şüpheli tutuklanırken bu sayı 1950 y1lında 1232 'ye yükselmiştir. ${ }^{17}$

Stalin rejiminin aldığ 1 bu tedbirler, Yahudi lobisini harekete geçirdi ve uluslararası camiada Sovyet yönetimi Yahudi karşıtlı̆̆ ile suçlanmaya başlandı. Oysa Sovyetler, Birleşmiş Milletler'in Filistin topraklarında oluşturmayı hedeflediği İsrail devletini destekleyen ve İsrail'i ilk tanıyan ülkelerden birisi idi. Dahası 1948 yılında gerçekleştirilen ilk Arap-İsrail savaşında Sovyetler, Yugoslavya üzerinden Siyonistlere silah desteğinde dahi bulunmuştu. ${ }^{18}$ Stalin' in Siyonist İsrail devletini desteklemesinin temelinde ise İngiltere'nin bölgedeki etkinliğini kırma arzusu yatmaktayd $1 .{ }^{19}$ Ancak yukarıda belirtilen sebepler nedeniyle Stalin,

16 Rabinovich, Byt Yevreyem v Rossii, 488.

17 Kostyrchenko Taynaya Politika Stalina, 458.

18 Kozlov, Evreyi v Rossii, 200.

19 Esasında Sovyetlerin Filistin topraklarında konuşlanan sol temayüllü Siyonist oluşumlarla ikili ilişkileri 1920'li yılların başlarına dayanmaktadır. Kültürel ve ekonomik faaliyetlerin yürütülmesi ve zamanla bölgede hâkim İngiliz etkisini kırarak Sovyet nüfuzunun artırılması amaçlanmaktaydı. Bu çerçevede 1923 yılında gerçekleştirilen Moskova Uluslararası Tarım Fuarına, proleter Siyonizm teşkilatının lideri ve daha sonra İsrail'in ilk başbakanı olan David Ben-Gurion davet edilmişti. M. Agapov, "Nauchnyye i Kulturnyye Svyazi SSSR i Yevreyskogo Natsionalnogo Ochaga", European Humanities University, (Vilnius, Lithuania, Zhurnal Zeitschriften, Tom 7/2, 2012), 10. 
bir politik değişikliğe gitmek ve Araplardan yana cephe almak durumunda kaldı. Stalin açısından artık Yahudiler, Sovyetler Birliğinin ulusal çıkarları için pek de güvenilir bir topluluk değillerdir. Tüm bu gelişmelerin paralelinde bir taraftan Sovyet bürokrasisinde var olan Yahudi etkisi önemli ölçüde azalma kaydederken, diğer taraftan da halk nezdinde Yahudi karşıtlığı tırmanışa geçti. G. V. Kostyrchenko "Kızıl Firavunun Esaretinde" başlıklı çalışmasında bu dönemde yaşanan Yahudi karşıtllğ̆ını detaylı bir biçimde ele almaktadır. Muhtemelen Kostyrchenko'nun Stalin'i Musa öncülüğünde Yahudilerin Mısır'dan çıkmalarını engelleyen Firavuna benzetmesinin altında 1948 yılı itibarıyla İsrail'e göç etmek isteyen Yahudilere konan yurt dışı yasağı yatmaktadır. Zira Sovyet Yahudilerinin İsrail'e göç etmelerinin önü ancak 1960'lı yıllarda kısmen açılmıştır. Yine Stalin dönemi Sovyet Rusya'sında Yahudilere yönelik baskı ve asimilasyonun olduğunu savunanlar, özellikle 1936-1938 yıllarında gerçekleştirilen repressiya yani baskı dönemlerini örnek göstermektedirler. Ancak bask1 yıllarında sadece Yahudilerin değil hemen her toplumdan bireylerin zulme uğradığı bilinen bir gerçektir. Örneğin araştırmacı Kozlov'un aktardığı bilgilere göre sadece 1937-1938 yılları içerisinde 681,7 bin insan hakkında ölüm fermanı çıkartılmıştır. Diğer yıllarda öldürülen insanları ve sürgünde hayatlarını kaybedenleri de eklediğimizde 1930 ile 1940 yılları arasında 5 milyonun üzerinde Sovyet insanının etkilendiğini söylemek mümkündür. ${ }^{20} \mathrm{Bu}$ rakamlar söz konusu dönemlerde sadece Yahudilerin değil toplumun tüm kesimlerinin devlet eliyle kıyıma maruz bırakıldığını ortaya koymaktadır. Ancak İkinci Dünya Savaşı sonrası meydana gelen olaylar, Sovyet Yahudileri açısından bir hayal kırıklığı olarak tanımlanabilir. Zira bu dönem, Yahudileri hedef alan Stalin politikalarının uygulandığ 1 bir dönemdir. Bunun en görünür yüzü İkinci Dünya Savaşı boyunca açılan sinagogların, 1948'den itibaren yeniden kapatılmasıdır. Zira 1948'de İsrail'in kurulmasından sonra Yahudi milliyetçiliğinin görünür bir hale gelmesi, Yahudi dini ve milli kimliğinin temel taşıyıcısı olarak görülen sinagogların kapatılmasına neden oldu. Bu çerçevede 1949 y1lında 180 civarında olan Sinagog sayıs1 1952 yılına gelindiğinde 136'ya kadar geriledi. ${ }^{21}$ Yine bu y1l itibarı ile Sovyetlerin Siyonizm'le olan mücadelesi daha küresel bir hal aldı. Başta Polonya olmak üzere Romanya, Bulgaristan, Macaristan ve Çekoslovakya gibi Sovyet etkisi altında olan Doğu Avrupa ülkelerinde varlık gösteren tüm Siyonist oluşumların faaliyetleri sonlandırıldı. 1952 yılı itibariyle İsrail politikalarının ABD’nin çıkarları doğrultusunda şekillendiği kanısı netlik kazanınca, Sovyet etkisi altında bulunan ülkelerden İsrail'e yönelik Yahudi göçü tamamen durdurulurken, Birleşmiş Milletler kurulunda da İsrail'i desteklemekten vaz geçildi. ${ }^{22}$

20 Kozlov, Evreyi v Rossii, 177.

21 Kostyrchenko, Taynaya Politika Stalina, 198.

22 Kostyrchenko, Taynaya Politika Stalina, 500. 
Sovyet-İsrail ilişkilerinde soğuk rüzgârların estiği bir ortamda Stalin'in rahatsızlanması, dikkatlerin Kremlin'de görevli doktorların üzerine çevrilmesine neden oldu. Uluslararası bir Yahudi milliyetçi örgüt ile (American Jewish Joint Distribution Committee) ilişkisi olduğu ileri sürülen Kremlin doktorlarının, Stalin ve üst düzey Sovyet yöneticileri zehirleme girişiminde bulundukları iddia edilmekteydi. $\mathrm{Bu}$ iddia zamanla Stalin tarafından da kabul gördü ve Kremlin doktorları hakkında kapsamlı bir soruşturma başlatıldı. Bu çerçevede başta Profesör Aleksey Andreyevich Busalov olmak üzere onlarca doktor tutukland1. ${ }^{23}$

Sovyet yönetiminin Yahudilere yönelik izlediği bu politikalar ve alınan kat1 tedbirler, Rus toplumu nezdinde de bir karşılık bulmaktaydı. Bu duruma 1953 Şubatında Tel Aviv'de bulunan Sovyet konsolosluğuna atılan bombanın da eklenmesi, toplumda mevcut Yahudi karşıtlığını bir üst aşamaya taşıdı. Tüm bu gelişmeler sonucunda bir taraftan Yahudi karşıtllı̆ı belirgin hale gelirken, diğer taraftan da Sovyet-İsrail ilişkileri tarihinde ilk kez kopma ile sonuçland ${ }^{24}{ }^{24}$ Başta Yahudi doktorlar olmak üzere onlarla ilişkisi tespit edilen diğer doktorlara da yönelik tutuklama furyasının hız kazandığı 1952 yılında ortaya yeni bir iddia atıldı. Bu iddiaya göre Stalin, Moskova başta olmak üzere büyük kentlerde bulunan tüm Yahudileri Sibirya'ya sürme planları yapıyordu. Söylentiler karşısında harekete geçen başta İsrail olmak üzere ABD ve İngiltere gazeteleri, Sovyetleri Yahudilere yönelik suç işlemekle itham ederken, durumu kendi lehine çevirmeyi amaçlayan İsrail, Stalin üzerinde uluslararası baskıyı artırmak suretiyle, Sovyet Yahudilerinin İsrail'e göçünün önünü açmaya çalışt1. ${ }^{25}$ Sovyet Yahudilerin Sibirya'ya sürgüne gönderileceği söylentisi ancak Stalin'in 5 Mart 1953 yılında ölümüyle birlikte son buldu. Sonuç itibariyle ne Yahudiler sürgün edildi ne de İsrail’e göç etmelerine onay verildi.

Dini inançların yok sayıldığı bir yönetim sisteminde, Yahudilerin halen bir sorun olarak görülüyor olmas1, meselenin sadece inanç farklılı̆̆ ile izah edilemeyeceğini ortaya koymaktadır. Bu hususta Dikiy, Abram Zisman'dan şu alıntıya yer vermektedir. 7 Mayıs 1960 tarihinde yayınlanan Novaya Zarya (New Dawn) gazetesinde kaleme aldığı bir yazısında anti-semitizme değinen Abram, sorunun köklerinin Yahudilerin tutum ve davranışlarında aranması gerektiğine şu ifadelerle dikkat çekmektedir:

"Tüm dünyada antisemitizm dalga dalga yayılmış durumdadır. Bazen küllenirken bazen de yeniden alevlenmektedir. Peki, neden böyle oluyor? Neden bir anti Fransız anti İtalyan veya anti İspanyol sorunu söz konusu olmamaktadır? Zira bu

23 Kostyrchenko, Taynaya Politika Stalina, 643.

24 Rabinovich, Byt Yevreyem v Rossii, 552.

25 Kostyrchenko, Taynaya Politika Stalina, 673. 
milletlere ait insanlar da dünyanın çeşitli coğrafyalarında yaşamaktalar. Neden sadece bir ülkede değil de hemen dünyanın her yerinde bir Yahudi karşıtllı̆ğndan söz edilmektedir? Her ne kadar antisemitizm kınanıyor ve halkların eşitliği ön plana çıkartılıyor ise de antisemitizm varlığını korumaya devam etmektedir. Eğer gerçekçi olmak gerekir ise biz antisemitizmi çağrıştıran sebeplerin nelerden kaynaklandığı sorusuna samimi ve hakkaniyet ile yanıt vermez ve kendi tutum ve davranışlarımızı gözden geçirmez isek bu sorun ilelebet var olmaya devam edecektir." ${ }^{26}$

\section{Stalin Sonrası Dönem Rusya Yahudilerinin Durumu}

Stalin'in 1953 yılında ölmesi ile birlikte Sovyet tarihinde yeni bir dönem, Nikita Kruşçev dönemi başladı. İlk iş olarak Kruşçev, Stalin kültü olarak ta bilinen olguyu yıktı ve kısmen özgürlüklerin önümü açtı. Yedi durum, Sovyet Yahudileri için de bazı olanakların sağlanmasına imkan tanıdı. Bunlardan ilki yeniden İbranice (İdiş) gazete ve dergi yayınının önündeki engellerin kaldırılmasıdır. Nitekim 1961 yılı itibarıyla Yahudiler Sovetish Heymland (Sovyet Anavatanı) adıyla dergi yayınlama hakkına kavuştular. Bir diğer gelişme ise 1971 yılından itibaren Yahudilerin yönelik yurtdışı yasağının kaldırılmasıdır. Zira daha önce yurtdışına çıkmak neredeyse imkânsız iken 1956 y1lı itibarıyla sadece 750 Yahudi'nin İsrail’i ziyaret etmesine izin verilmişti. Bu sayı ilerleyen yıllarda binleri bulacaktır. 1971 yılından itibaren ise İsrail'e yönelik Yahudi göçünün önü de kısmen açılmış oldu. Sadece 1971 yılı içerisinde 13 bin Yahudi İsrail'e göç ederken bu sayı bir yıl sonra yani 1972 yılında 32 bine çıktı. 1973 yılında ise 300 bin Yahudi'nin İsrail'e göç etme talebiyle dilekçe verdiği görülmektedir. Ancak bu sayıdan 35 binine onay çıkarken geri kalanı reddedilmiştir. ${ }^{27} 1970$ 'li yıllarda Rusya Yahudilerinin İsrail'e göç etme isteklerini birden fazla nedeni vardır. Bunların başında Yahudi inancında önemli bir yeri olan "vadedilmiş topraklara" geri dönüş arzusu gelmektedir. İkinci olarak ise ülke genelinde her zaman varlığını koruyan bir Yahudi karşıtlığının olmasıdır. Bir diğer neden ise, Sovyetler Birliğinin izlemekte olduğu Siyonizm karşıtı politikalardır. Arap-İsrail savaşlarında Sovyetlernin Arapların yanında yer alması, özellikle Siyonizm destekçisi Yahudilerin Sovyetlere olan aidiyetini sorgulamalarına neden olmaktaydı. Yahudileri İsrail'e göç etmeye iten bir diğer sebep ise uzun yıllardan beri uygulanan asimilasyon politikalarıdır. Bir taraftan dini inançların baskı altında tutulması diğer taraftan da İbranice eğitim veren müesseselerin minimize edilmesi, Yahudilerin kendi inanç ve gelenekleri çerçevesinde eğitilmelerini zorlaştırmaktaydı. Örneklendirmek gerekirse, 1970 yılında yapılan bir araştırmaya göre Sovyet

26 Andrey Dikiy, Yevreyi v Rossii I v SSSR, Russko-Yeveyskiy Dialog, (Blagovest, Novosibirsk, 2005), 404.

27 Kozlov, Evreyi v Rossii, 208. 
Yahudilerinin \%17,7'sinin ana dilinde okuyup yazabildiğini ortaya koymaktadır. Yine 1979 verilerine göre ise bu oran \%14'e kadar gerilemiştir. ${ }^{28}$ Isște tüm bu nedenler Yahudilerin Sovyetleri terk ederek İsrail'e göç etmelerine sebep olmaktaydı.

1960'lı yıllardan itibaren İsrail'e yönelik göç imkânının kısmen dahi olsa sağlanması, akademi ve sanat dünyasında mevcut Yahudi etkinliğinin de giderek azalmasıyla sonuçlandı. Örneğin 1960 yılında akademi camiasının \%9,6's1, Yahudi bilim insanlarından oluşurken bu oran 1973 verilerine göre \%6,1'e kadar geriledi. Buna rağmen Yahudilerin başta avukatlık ve doktorluk olmak üzere önemli meslek alanlarındaki etkinlikleri diğer etnik gruplara oranla çok daha yüksek düzeyde kalmaya devam etmekteydi. 1960 istatistiklerine göre Sovyetler Birliğinin toplam nüfusu 208 milyon civarındadır. Bunlardan 2,5 milyonu Yahudilerden oluşuyordu. 208 milyonluk Sovyet nüfusu içerisinde 2,5 milyon civarında olan Yahudilerin Bazı mesleklere göre yüzdesi ise şu şekildedir: Hekimlik mesleğinin \%14,7,'sini, Akademinin \%11'rini, Avukatlık mesleğinin \%10,4'ünü, gazeteci ve yazarların $\% 8,5^{\prime}$ ini ve sanat camiasının da \%7'sini Yahudiler oluşturmaktayd.$^{29} 1970$ verilerine göre ise SSCB'nin toplam nüfusu 240 milyona ulaşırken, aynı dönemlerde Sovyet Yahudilerinin toplam nüfusu 2 milyon 150 bine gerilemiştir. Bu ise 1960 ile 1070 yılları arasında 350 bin civarında Yahudi'nin SSCB'den ayrıldı̆̆ını ortaya koymaktadır. Sovyet Yahudilerinin ilerleyen dönemlerde de İsrail'e yönelik göçleri devam etti. Öyle ki 1979 yılında toplam 2 milyon 150 bin civarında olan Yahudi sayıs1, 1989 verilerine göre 1 milyon 800 bine gerilemişti. ${ }^{30}$ Toplamda ise 1960 yılından SSCB'nin dağılamasın kadarki zaman zarfında 1 milyona yakın Yahudi'nin SSCB'yi terk ettiğini söylemek mümkündür. SSCB'yi terk eden Yahudilerin önemli bir bölümü İsrail'e göç ederken, bir kısmı da Amerika başta olmak üzere diğer Batılı ülkelere gidiyorlardı. 1991 yılında SSCB feshedildiğinde eski Sovyetler Birliği sınırları içerisinde 1 milyon 800 bin civarında Yahudi yaşamaktaydı. Sovyetler dağıldıktan sonra bu Yahudilerin büyük bir bölümü de İsrail'e göç ettiler.

\section{Eğitim ve İnanç Alanında Sovyet Yahudilerinin Durumu}

İkinci Dünya Sava ve sonrasında Sovyet Yahudilerinin eğitim ve inan alanlarında da bazı gelişmeler meydana gelmiştir. Özellikle eğitim alanında Yahudilerin aktif oldukları bilinen bir husustur. Bu başlık altında Sovyet Yahudilerinin Sovyet akademisindeki konumu üzerinde durulacaktır. Ayrıca resmi ateizm ideolojisini benimseyen Sovyetlerin Yahudi inancı ve ibadetleri hususunda takındığı tavır ve davranışlara yer verilecektir.

28 Rabinovich, Byt Yevreyem v Rossii, 647.

29 Dikiy, Evreyi v Rossi i SSSR, 229.

30 Rabinovich, Byt Yevreyem v Rossii, 668. 


\section{Eğitim Alanında Sovyet Yahudileri}

1917 Bolşevik Devrimi sonrası Yahudilerin oluşturulan yeni düzen içerisinde aktif rol üstlenmeleri ve ilerleyen yıllarda devletin üst kademelerinde önemli pozisyonlara gelmeleri, Sovyetler Birliğinde Yahudi etkisini doruk noktaya çıkartmıştı. Artık akademiden sanata, medyadan edebiyata ülkenin hemen her alanında Yahudi etkisi kendisini gösteriyordu. Esasında Yahudiler Haskala hareketinden beri eğitime çok önem verdiler ve bulundukları ülkenin eğitim sistemine uyum sağlamaya çalıştılar. Bu çerçevede Sovyetlerde eğitim veren yükseköğretim kurumlarından da olağan güçleriyle yararlandılar. İstatistiki veriler ile belirtecek olur isek, 1929 yılında ülke genelinde mevcut tüm akademi çalışanlarının \%13,6'si Yahudilerden oluşmaktaydı. Bu oran 1937 yılında \%19,6'ya kadar yükselmektedir. ${ }^{31}$ Sovyetler Birliği'nde mevcut üç milyon civarındaki Yahudi nüfus göz önünde bulundurulduğunda bu oranın çok yüksek olduğu görülecektir. Akademi alanında mevcut Yahudi etkinliği kısmen 1937-1938 repressiya yıllarında azalmaya yol açmışsa da bu etki İkinci Dünya Savaşı sonrasına kadar devam eder.

Repressiya süreci tüm Sovyet halklarını etkilediği gibi Yahudileri de önemli ölçüde kıyıma uğratmıştır. Lakin 1939 verilerine bunca sürgün ve idamlara rağmen Yahudilerin bazı alanlardaki etkinliklerini sürdürmeye devam ettirdiğini ortaya koymaktadır. Örnek verilecek olur ise ülke genelinde mevcut tüm mühendislerin \%14 Yahudilerden müteşekkildi. Yine Sovyetler Birliğinde mevcut tüm yönetici kadrosunun \%7'si halen Yahudilerin kontrolündeydi. Diğer taraftan doktorluk kadrosunun \%27, öğretmenlerin ise \%3'ü Yahudilerden oluşmaktayd1..$^{32} \mathrm{Bu}$ durum İkinci Dünya Savaşından sonra İsrail Devletinin kurulmasına değin devam etmektedir. Yukarıda temas edildiği üzere İsrail'in kurulması ve Siyonizm'in belirgin bir hale gelmesi, Stalin Rusya'sının bazı tedbirler almasina neden oldu. Bürokrasi, medya ve sanat alanında önemli tedbirler alınmaya ve bu alanlarda mevcut Yahudi etkinliği azaltılmaya çalışıldı. Bu alanlardan biri de Sovyetler Bilimler Akademisidir. Örneğin 1946 y1lı verilerine göre on akademik enstitüde görev alan 765 akademisyenden 208'i Yahudi kökenliydi. Buna benzer tablo SSCB'de mevcut hemen her yüksek eğitim kurumu için geçerliydi. Bu durumu kontrol altına almak maksadıyla üst düzey personelin sertifikalandırılması adı altında akademide kapsamlı bir temizlik faaliyeti başlatıldı. 1947 yılında Merkez Komiteye sunulan rapora göre SSCB Bilimler Akademisine yapılan yüksek lisans ve doktora programlarına kabullerde Yahudi sayısında azalma gözlemlenmektedir. Şöyle ki bir önceki sene 317 (\%17,6) olan Yahudi akademisyenin sayıs1, 1948 yılında 132'ye $(\% 9,1)$ kadar düşürülmüştür. ${ }^{33}$

31 Rabinovich, Byt Yevreyem v Rossii, 275.

32 Rabinovich, Byt Yevreyem v Rossii, 277.

33 Kostyrchenko, Taynaya Politika Stalina, 557. 
Tablo 1.

1950-1952 yıllarinda Akademide mevcut Yahudi orant ${ }^{34}$

\begin{tabular}{|l|c|c|c|c|c|c|}
\hline \multirow{2}{*}{ Araştırmacı kategorisi } & \multicolumn{4}{|c|}{ SSCB Bilimler Akademisine Kayıtlı Bilimsel Araştırmac1 Oranı } \\
\cline { 2 - 7 } & \multicolumn{2}{|c|}{ Genel } & \multicolumn{2}{c|}{ Rus } & \multicolumn{2}{c|}{ Yahudi } \\
\cline { 2 - 7 } & $\mathbf{1 9 5 0}$ & $\mathbf{1 9 5 2}$ & $\mathbf{1 9 5 0}$ & $\mathbf{1 9 5 2}$ & $\mathbf{1 9 5 0}$ & $\mathbf{1 9 5 2}$ \\
\hline Akademisyen & $133(\% 100)$ & $117(\% 100)$ & $106(\% 79,7)$ & $93(\% 79,5)$ & $11(\% 8,3)$ & $10(\% 108,5)$ \\
\hline Bilim Doktoru & $941(\% 100)$ & $1061(\% 100)$ & $750(\% 74,9)$ & $806(75,9)$ & $147(\% 15,6)$ & $142(\% 13,3)$ \\
\hline Bilim Aday1 & $2849(\% 100)$ & $3662(\% 100)$ & $2080(\% 73,0)$ & $2703(\% 73,8)$ & $428(\% 15,0)$ & $473(\% 12,9)$ \\
\hline
\end{tabular}

Yukarıda verilen rakamlardan da anlaşılacağı üzere 1946-1950 yılları arasında gerçekleştirilen Akademiyi Yahudi etkisinden kurtarma politikası kısmen sonuç vermiştir. Lakin yine de toplam Sovyet nüfusuna kıyasla Yahudilerin akademideki temsil oran1 \%10'un üzerindedir.

\section{Bazı Dini Uygulamalarda Sovyet Yahudileri}

İdeolojik tutumları gereği Bolşevik yönetimi, tüm dini inançların faaliyetlerini kısıtladı ve sahip oldukları mal varlıklarına da el koydu. Her ne kadar Bolşevik devrimini gerçekleştiren kadroların önemli bir bölümü Yahudilerden oluşuyorduysa da benimsenen ateizm ideolojisi, tüm dini inançları etkilediği gibi, Yahudi inancını da etkiledi. Devrimden iki ay sonra yani 23 Ocak 1918 tarihinden itibaren dini devletten ve okulları da dinin (kilisenin) etkisinden ayırmak suretiyle yeni bir süreci başlatan Bolşeviklerin, 28 Aralık 1920 tarihi itibarıyla, Melamedlerin Yahudi çocuklarına din eğitimi verdiği Heder okullarının da kapatılmasını kararlaştırdılar. ${ }^{35}$ Sovyetler Birliğinde bu tarihten itibaren Heder okulları resmi olarak bir daha faaliyet göstermedi. Ancak Yahudi çocuklara yönelik din eğitimi, uzun yıllar boyunca gayri resmi olarak verilmeye çalışıldı.

Sovyetlerin din karşıtı politikaları iki farklı koldan devam ediyordu. Bunlardan ilki Baskı ve yasaklar üzerinden dini inanışların ortadan kaldırılmasını içerirken bir diğeri de okullarda verilen resmi ateizm ideolojisi kapsamında din karşıtı propagandadan oluşmaktaydı. İkinci Dünya Savaşı ve sonrası yıllarda ise kısmı ölçüde başta Rus Ortodoks Kilisesi olmak üzere diğer dini yapıların varlık göstermesine izin verildi. Bu kapsamda bazı bölgelerde daha önce kapatılan veya işlevsiz hale getirilen Sinagogların yeniden faaliyet göstermesine müsaade edildi. ${ }^{36}$ Artık Sinagoglarda dini bayramları kutlama ve günlük ibadetlerin yerine getirilmesindeki zorluklar

34 Kostyrchenko, Taynaya Politika Stalina, 559.

35 Lebedev, "Politika Sovetskoy Vlasti v Otnoshenii İudeyskoy Religiis", 31.

36 Aleksandr Kats, Yevrei, Khristianstvo, Rossi, Ot Prorokov do Gensekov, (Moskva, ABU, 2006), 320. 
kısmen aşılmışsa da Yahudi inanışı açısından son derece önemli olan yeni doğan erkek çocukların sünnet edilmesi gibi dini törenlerin yapılması yasak statüsünde kalmaya devam ediyordu. Devletin takibi ve yasağına rağmen Yahudiler doğum ritüelleri ve özellikle sünnet merasimlerini gizlilik içerisinde sürdürmeye devam etmekteydiler.

Ateizmi benimseyen Sovyet ideolojisi, Sovyetler Birliğinin İkinci Dünya Savaşına dâhil olduğu tarihe kadar din ve dini uygulamalara oldukça katı bir yaklaşım sergiliyordu. Ancak savaşın Sovyetlere sıçraması, Stalin'in din politikasında bazı değişikliklere yol açtı. Bunun temel nedeni ise Sovyetlerin Hitler Almanya'sının hızlı ilerleyişi karşısında ABD'nin desteğine ihtiyaç duyuyor olmasıydı. ${ }^{37} \mathrm{Bu}$ kapsamda din karşııtı bir rejim algısını değiştirme refleksi ile az da olsa dini yapıların yeniden faaliyet göstermesine göz yumuldu. Bu süreç savaş sonrası yıllarda da kısmen devam edecektir. Bu çerçevede Yahudilerin de dini ritüellerini merkezi yerlerde faaliyet yürüten bazı sinagoglarda gerçekleştirmelerinin önü açılmış oldu. Yukarıda da belirtildiği üzere Yahudilerin haftalık ve yıllık ibadetleri olan Şabat, Roş-Haşana, Yom Kipur, Sukkot, Hanuka ve diğer ritüellerin uygulanmasında önemli bir zorluk yaşanmazken, özellikle yeni doğan bebeklerin sünnet (Brit Milah) ${ }^{38}$ merasimi ciddi sorunlara neden oluyordu. Öncelikle Sovyet yasaları bebeklerin sünnet edilmesini yasaklandığından bu tür eylemler suç sayılmaktaydı. Bu yasağın temelinde ise yapılan sünnet operasyonlarının Sovyet yönetimi açısından tamamıyla ilkel yöntemlerle gerçekleştiriliyor olması yatmaktaydı. Zira Yahudi inancına göre yapılan sünnet Tanrı ile yapılan ahitleşmenin göstergesidir ve bu süreç bir ritüel halinde Haham tarafından gerçekleştirilmelidir. Bu ritüelde öne çıkan önemli hususlardan biri, sünneti gerçekleştiren hahamın kesilen yerden gelen kanı ağzı ile emerek temizlemesidir. Bu şekilde zararlı kanın bebeğin vücudundan atılacağı düşünülmektedir. Bu ise bazı hallerde bebeğin enfeksiyon kapmasına hatta hayatının tehlikeye düşmesine dahi yol açmaktayd $1 .{ }^{39}$ Ancak Yahudiler, bu yasağa rağmen doğan çocukları gizlilik içerisinde Yahudi dininin kuralları çerçevesinde sünnet etmeye devam etmekteydiler. Dolayısıyla enfeksyon kapan ve hastaneye kaldırılan bebekler olduğunda olay adli bir vakaya dönüşmekte ve sorumlular hakkında Sovyet yasalarına aykırı davranmaktan dolayı ceza verilmekteydi. Neredeyse

37 Vladislav Tzipin, İstoriya Russkoy Tserkovi 1917-1997, (Moskova, İzdatelstva, SpasoPreobrajenskogo Vallamskogo Monastırya, 1997), 270.

38 Yahudilikte sekiz günlük çocukların sünnet edilmesi geleneği Hz. İbrahim'e kadar geri gitmektedir. Tanah'ın Yaratılış 17: 9-14'de yer alan bilgilere göre İbrahim Tanrı ile bir ahitleşme sonucu 90 yaşında iken sünnet olmuştur. Bu gelenek günümüze değin doğan her Yahudi çocuk için uygulanagelmektedir. Bu uygulama ancak yetkili Haham tarafindan gerçekleştirilmektedir. Encyclopedia of Judaism, Sara E. Karesh and Mitchell M. Hurvitz, (New York, 2006), 70. 
tamamı Aşkenazi Yahudilerden oluşan Sovyet Yahudileri, inançlarının gereği olan sünnet ritüelini yasak olmasına ve ciddi cezalar verilmesine rağmen kesintisiz devam etmişlerdir. Sünnet dışında başta Pidyon Haben ${ }^{40}$ olmak üzere geri kalan tüm ritüeller ise Sinagoglarda Haham öncülüğünde gerçekleştirilmeye çalış1lmıştır.

\section{Sonuç}

İkinci Dünya Savaşı boyunca Almanlar, Yahudilere acımasız davrandılar ve Rusya'ya açtıkları savaşı da Moskova'yı kuşatan Bolşevik Yahudilere karşı bir savaş olarak ilan ettiler. Almanlar bu iddia ile yıllardan beri ateizmin baskısı altında ezilen Ortodoks Rus toplumunun sempatisini kazanarak Almanlara karş1 oluşacak direncin kırılmasını hedefliyorlardı. Lakin Rus Ortodoks Kilisesi, Alman saldırısına karşı devletin yanında olduğunu deklere ederek Nazilerin bu hamlesini boşa çıkartmaya çalıştı. Almanların hızlı ilerleyişi, sınır boylarında bulunan ve dahi alman işgalinden kaçan yüzbinlerce Yahudi'nin Sovyetlere sığınmasıyla sonuçlandı. Bu Yahudilerin önemli bir bölümü cephe hattından çok uzaklara Rusya'nın iç kesimlerine doğru göç ettirildiler. Böylelikle yüzbinlerce Yahudi Sovyetlerin Batısından doğusuna göç ettirilmiş oldular. Savaş boyunca beş yüz bin civarında Yahudi Sovyet cephelerinde Almanlara karşı savaştırıldı. Bu süreçte toplumsal desteği sağlamak için Stalin, bazı kararlara imza attı. Bunların başında dini toplulukların inançlarını yerine getirmeleri konusunda var olan yasakların gevşetilmesi gelmektedir. Dinlere karşı bu olumlu yaklaşım Yahudi cemaatini de etkiledi ve onlarca sinagog yeniden dini hizmet vermeye başladı. Savaştan sonraki yıllarda ise özellikle 1948 yılında İsrail'in kurulması ile birlikte Sovyetlerin Yahudi politikasında birden fazla değişiklik meydana gelmeye başladı. İlk aşamada İsrail'i destekleyen Sovyetler, İsrail'in Batı bloğuna yaklaşması ile birlikte bu desteğini çekmemekle kalmadı, İsrail'e karşı Arap devletlerini desteklemeye yöneldi. Yahudilerin İsrail'e göç talepleri Stalin rejimini sert tedbirler almaya sevk etti ve bu çerçevede Yahudilere yönelik takip başlatıldı. Aynı zamanda dini, kültürel ve eğitim alanlarında da ciddi kısıtlamalar getirildi. Ayrıca Sovyet Yahudilerinin yurtdışına çıkışları da engellendi. Tüm bu gerginlikler üzerine 1953 yılında Tel Aviv'de Rusya konsolosluğuna yapılan bombalı saldırı iki ülke arasındaki diplomatik ilişkilerin kopması ile sonuçlandı.

Stalin'in ölümünden sonra partinin başına gelen Kruşçev, baskıcı politikalarda kısmi değişikliğe gitti ve Yahudilere yönelik yapılan takiplere son verdi. Böylelikle yeni dönem Sovyet Yahudileri açısından yeni umutları da doğurmuş oldu. Yahudilerin yurtdışı yasakları da kısmen kaldırıldı ve İsrail'e yönelik göçlerin belli sayıda gerçekleşmesine onay verildi. Yahudiler yeniden eğitim ve sanat alanlarında etkin 40 Sayılar: 15-16. 
olmaya başladılar. Yeniden faaliyete başlayan sinagoglarda dini vecibelerini yerine getirme hususunda var olan kısıtlamalar da ortadan kaldırılmış oldu. Sadece sünnet merasimi konusunda devletin yasağ devam etmekteydi ki bu uygulama da evlerde haham eşliğinde gerçekleştirilmekteydi. Özetle Yahudiler tarih boyunca yaşadıkları toplumlar arasında inançları nedeniyle baskı ve takibe, bazı hallerde ise kıyımlara maruz birakıldılar. Ancak Sovyetler Birliğinde Yahudilerin baskı veya takibe maruz kalmalarının temelinde dini hassasiyetlerden daha ziyade, siyasi gerekçelerin ön plana çıktığını söylemek mümkündür. Yahudilerin Devletin çeşitli kademelerinde etkili olmaları Rus toplumunu ve dolayısıyla da siyasileri rahatsız ederken, İsrail'in Batı eksenli politikaları ve Rusya Yahudilerinin İsrail'e yönelik göç talepleri Sovyet yönetimini bazı tedbirler almaya sevk etmiştir. Dolayısıyla Çarlık Rusya'sı zamanında dini gerekçelerle baskı gören Yahudiler, Sovyet Rusya'sında da İsrail'e olan bağlılıkları nedeniyle takibe maruz kalmışlardır.

Hakem Değerlendirmesi: Dış bağımsız.

Çıkar Çatışması: Yazar çıkar çatışması bildirmemiştir.

Finansal Destek: Yazar bu çalışma için finansal destek almadığını beyan etmiştir.

Peer-review: Externally peer-reviewed.

Conflict of Interest: The author has no conflict of interest to declare.

Grant Support: The author declared that this study has received no financial support.

\section{Kaynakça/References}

Agapov, Mikhail Gennadievich., "Nauchnyye i Kulturnyye Svyazi SSSR i Yevreyskogo Natsionalnogo Ochaga", European Humanities University, Vilnius, Lithuania, Zhurnal Zeitschriften, Tom 7/2, 2012. (Agapov, Mikhail Gennadievich , SSCB'nin Bilimsel ve Kültürel İlişkileri ve Yahudi Ulusal Yurdu, 7/2, 2012).

Dikiy, Andrey., Yevreyi v Rossii İ v SSSR, Russko-Yeveyskiy Dialog, Blagovest, Novosibirsk, 2005. (Dikiy Andrew, Rusya ve SSCB'deki Yahudiler, Novosibirsk, 2005).

Encyclopedia of Judaism, Sara E. Karesh and Mitchell M. Hurvitz, New York, 2006.

Kats, Aleksandr, Yevrei, Khristianstvo, Rossi, Ot Prorokov do Gensekov, Moskova, ABU, 2006. (Alexander Katz, Yahudileri, Hıristiyanlık Rusya, Yayınevi: ABU, AST, 2006).

Kostyrchenko, Gennadiy Vasilyevic, Taynaya Politika Stalina. Vlast i Antisemitizm Moskva., Mezhdunarodnye Otnosheniya, 2003. (Kostyrchenko Gennady Vasilievich, Stalin'in Gizli Politikası. Hükümet Anti-Semitism, Yayınc1, Uluslararası İlişkiler, Moskova, 2003).

Kozlov, Viktor, Yevrei v Rossii-SSSR, Realii Zhizni i Mify, Moskova, Russkaya Pravda, 2010. (Kozlov, Viktor Ivanovich, Rusya'daki Yahudiler - SSCB: Gerçekler ve Mitler, Moskova, Rus Gerçeği, 2010).

Kutsal Kitap, The Bible Society in Turkey (Kitabı Mukaddes Şirketi) Yeni Yaşam Yayınları., 2006. 
Lebedev, A., V. Pichukov, "Politika Sovetskoy Vlasti v Otnoshenii İudeyskoy Religii, European Humanities University, Vilnius, Lithuania, Zhurnal Zeitschriften, Tom 7/2, 2012. (Lebedev, A., V. Pichukov, "Sovyet Hükümetinin Yahudi Dinine Münasebeti v Otnoshenii İudeyskoy Relti, European Humanities University, Vilnius, Lithuania, Zhurnal Zeitschriften, Tom, 7/2, 2012.

Rabinovich, Yakov, Bit Evreyem v Rossii: Spasibo Solojenitsinu, Algoritma, Moskova, 2005. (Rabinovich Yakov, Rusya'da Yahudi Olmak; Solzhenitsyn'e Teşekkürler, Moskova, 2005).

Solzhenitsyn, Aleksandr Isayevich, Dvesti Let Vmeste, (1917-1995) Chast Vtoraya, Russkiy Put, 2002. (Alexander Solzhenitsyn: Birlikte İki Yüz Yll, Bölüm 2, (1917-1995) Rus Yolu, 2002).

Tzipin, Vladislav, Ístoriya Russkoy Tserkovi 1917-1997, Moskova, İzdatelstva, Spaso-Preobrajenskogo Vallamskogo Monastırya, 1997. (V. Tsipin, Rus Kilisesi Tarihi 1917-1997, Yayınevi, SpasoPreobrazhensky Vallamsk Manastırı, Moskova, 1997).

Ugolovnyy Kodeks Rossiyskoy Sotsialisticheskoy Federativnoy Sovetskoy Respubliki, 1922, Statya 58-10. (Rusya Sosyalist Federatif Sovyet Cumhuriyeti Ceza Kanunu, 1922, Madde, 58-10). 
